\title{
KEMAMPUAN PEGAWAI TERHADAP PROFESIONALISME PELAYANAN PUBLIK
}

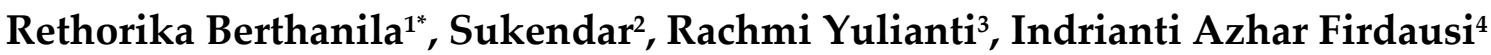 \\ ${ }^{123}$ Program Studi Administrasi Publik \\ ${ }^{4}$ Program Studi Ilmu Komunikasi \\ Fakultas Ilmu Sosial, Politik dan Ilmu Hukum Universitas Serang Raya
}

*Coressponding Author : Rethorikaberthanila@gmail.com

\begin{abstract}
Abstrak
Kemampuan pegawai merupakan bagian kepribadian yang mendalam dan melekat kepada seseorang serta perilaku yang dapat diperidiksi pada berbagai keadaan dan tugas pekerjaan, sehingga suatu kegiatan yang dilakukan oleh seseorang atau sekelompok pegawai untuk memenuhi kepentingan orang lain dengan berdasarkan kepada prosedur dan metode yang telah ditetapkan agar dapat diterima oleh orang lain sesuai dengan yang diharapkan. Artikel ini betujuan menelaah seberapa besar pengaruh kemampuan pegawai terhadap profesionalisme pelayanan administrasi di Kantor Kecamatan Picung Kabupaten Pandeglang. Metode penelitian yang digunakan adalah pendekatan kuantitatif, menggunakan Analisis korelasi produc moment, dengan pengumpulan data ini menggunakan kuesioner, jumlah sampel sebanyak 82 orang. Hasil yang ditemukan bahwa kemampuan pegawai mempunyai pengaruh yang kuat terhadap profesionalisme pelayanan adminsitrasi, apabila kemampuan pegawai meningkat maka prfesionalisme pelayanaan adminsitasi juga akan mengalami peningkatan yang berarti bahwa kemampuan pegawai telah sesuai dengan yang dibutuhkan organisasi sehingga dapat memberikan pelayanan administrasi kepada masyarakat secara profesional.
\end{abstract}

Kata Kunci : Kemampuan Pegawai, Profesionalisme, Pelayanan Publik

\section{Abstract}

The ability of employees is a part of a deep personality and is inherent to someone and behavior that can be reflected in various circumstances and work tasks, so that an activity carried out by a person or group of employees to meet the interests of others based on procedures and methods that have been set to be acceptable by others as expected. This article aims to examine how much influence the ability of employees on the professionalism of administrative services in the Picung District Office in Pandeglang Regency. The research method used is a quantitative approach, using produc moment correlation analysis, by collecting this data using a questionnaire, the total sample of 82 people. The results found that the ability of employees has a strong influence on the professionalism of administrative services, if the ability of employees increases the professionalism of administrative services will also increase which means that the ability of employees is in accordance with what is needed by the organization so that it can provide administrative services to the community professionally.

Keywords: Employee Ability, Professionalism, Public Service 
Jurnal Administrasi Negara

ISSN : 2598-4039 (Online)

ISSN : 2302-2231 (Print)
Rethorika Berthanila, Sukendar,

Rachmi Yulianti, Indrianti Azhar Firdausi

Universitas Serang Raya

\section{PENDAHULUAN}

Perilaku pegawai pada hakekatnya ditimbulkan dari kebiasaankebiasaan yang dimiliki oleh masingmasing individu pegawai yang diperoleh dari lingkungan, tempat belajar dan keluarga yang akan dibawa ke dalam suatu organisasi dimana pegawai itu bekerja, sehingga bila perilaku individu dan perilaku organisasi dapat berinteraksi dengan baik, maka akan terwujud suatu perilaku individu dalam organisasi yang akan berdampak positif bagi organisasi dan pegawai itu sendiri.

Untuk meningkatkan kemampuan atau kompetensi yang dimiliki oleh masing-masing pegawai, pimpinan harus mampu mengarahkan para pegawainya untuk berpikir ke masa depan dan memiliki kemampuan untuk membuat keputusan tentang bagaimana seharusnya ia bertindak, dengan demikian pegawai tersebut akan menjadi lebih fokus dan maksimal dalam melaksanakan pekerjaannya. Kompetensi dan profesionalisme pegawai selalu menjadi fokus dari semua gerakan, aktivitas, usaha, dan perubahan menuju pada kemajuan di dalam kelompok atau organisasi, selain itu merupakan agen primer untuk menentukan seberapa besar efektivitas pelayanan publik yang dapat organisasi berikan kepada masyarakatnya.
Kompetensi dapat dibagi dua yaitu kompetensi dasar (threshold competency) adalah karakteristik utama yang harus dimiliki seseorang untuk dapat melaksanakan pekerjaannya serta kompetensi bidang (differentiating competency) adalah faktor-faktor yang membedakan individu yang berkinerja tinggi atau rendah (Spencer \& spencer, 2003 : 197). Kompetensi merupakan perpaduan dari pengetahuan, keterampilan, nilai dan sikap yang direfleksikan dalam kebiasaan berpikir dan bertindak. Sedangkan menurut Robbins (2008 : 263) kemampuan (ability) merujuk kepada suatu kapasitas individu untuk mengerjakan berbagai tugas dalam suatu pekerjaan. Adapun unusr-unsur kemampuan pegawai terdiri dari, kemampuan intelektual, kemampuan fisik, kepribadian.

$$
\text { Profesionalisme pelayanan }
$$
publik pada dasarnya menyangkut aspek kehidupan yang sangat luas. Dalam kehidupan bernegara, maka pemerintah memiliki fungsi memberikan berbagai pelayanan publik yang diperlukan oleh masyarakat, mulai dari pelayanan dalam bentuk pengaturan atau pun pelayananpelayanan lain dalam rangka memenuhi kebutuhan masyarakat dalam bidang pendidikan, kesehatan, utlilitas, dan lainnya. Upaya meningkatkan profesionalisme dalam pelayanan public 
Jurnal Administrasi Negara

ISSN : 2598-4039 (Online)

ISSN : 2302-2231 (Print)
Rethorika Berthanila, Sukendar,

Rachmi Yulianti, Indrianti Azhar Firdausi

Universitas Serang Raya tidak hanya ditempuh melalui keputusan-keputusan sebagaimana yang telah pemerimtah buat, tetapi juga melalui peningkatan kemampuan aparat dalam memberikan pelayanan. Upaya ini dilakukan dengan cara memberikan berbagai materi mengenai manajemen pelayanan dalam diklatdiklat struktural pada berbagai tingkatan. Siagian (2000 : 160) mengemukakan bahwa profesionalisme seorang pegawai akan dapat dilihat dari kemampuan pegawai dalam tiga hal, yaitu kreativitas, Inovasi, responsivitas.

Kecamatan merupakan lembaga formal yang menjalankan proses pemerintah dalam memberikan pelayanan kepada masyrakat, selain itu kecamatan merupakan bagian dari rantai birokrasi pemerintahan kabupaten/kota. Oleh sebab itu diharapkan dapat mendorong pelaksanaan pelayanan public yang sesuai dengan visi dan misi kecamatan. Ada beberapa jenis pelayanan yang dilakukan oleh aparatur kecamatan yaitu pelayanan pengantar pembuatan Kartu Keluarga (KK), Pelayanan pengantar pembuatan Kartu Tanda Penduduk (KTP), Pelayanan pembutan Surat Keterangan Belum Nikah (SKBN), Pelayanan pembuatan Surat Keterangan Tidak Mampu (SKTM) pelayanan pembuatan surat keterangan tanda lapor diri (SKTLD). Fenomena yang terjadi dilapangan diantaranya mengenai kemampuan pegawai masih kurang maksimal, seperti kurangnya kemampuan yang dimiliki oleh para pegawai dalam menunjang terapainya tujuan organisasi, masih rendahnya moralitas yang dimiliki para pegawai, sehingga hal ini terlihat dari hilangnya budaya malu dalam diri pegawai bila melanggar peraturan yang telah dietapkan. Dari kedua fenomen tersebut menimbulkan masalah lain yaitu profesionalisme pelayanan administrasi masih rendah, terlihat dari indikasi pelaksanaan pelayanan yang cepat hanya didasarkan kepada mau tidaknya masyarakat membayar upah pelayanan yang telah diberikan, masih adanya pekerjaan pelayanan yang tidak dapat dselesaikan sesuai dengan waktu yang telah ditetapkan.

Penelitian tentang kemampuan, profesionalisme, dan pelayanan sudah dilakukan beberapa diantaranya (Darwin, 2015), (Mariana, 2016) yang menyatakan seharusnya pegawai diberikan kemampuan dan dibangkitkan kemauannya dalam bekerja, diberikan keleluasaan untuk bertindak dan mengambil sikap yang diperlukan agar dapat memberikan layanan yang maksimal kepada pelanggan/masyarakat. (Mandasari, 2014) hasil penelitiannya bahwa profesionalisme pegawai mempunyai 
Jurnal Administrasi Negara

ISSN : 2598-4039 (Online)

ISSN : 2302-2231 (Print)
Rethorika Berthanila, Sukendar,

Rachmi Yulianti, Indrianti Azhar Firdausi

Universitas Serang Raya pengaruh yang kuat dan bernilai positif serta signifikan terhadap kualitas pelayanan. Artinya apabila profesionalisme pegawai meningkat maka kualitas pelayanan publik yang dihasilkan juga akan mengalami peningkatan. Penelitian (Mandey, Mandey, \& Tulusan, 2015) menyatakan bahwa hasil penelitian ini menunjukkan ada indikasi kuat bahwa ketika aparat desa meningkat profesionalisme (tinggi) akan mendorong peningkatan kualitas layanan publik. Hasil ini konsisten dengan hasil analisis regresi linier sederhana dengan persamaan $\mathrm{Y}=2.062$ $+1.040 \mathrm{X}$, dan koefisien korelasi momen produk $r$ sebesar 0,809. Selanjutnya (Noordegraaf, 2016) hasil penelitiannya menyatakan banyak layanan publik dihasilkan oleh pekerja profesional yang menangani kasus dan klien berdasarkan pengetahuan dan keterampilan professional, profesional tidak hanya dikelola dan diukur; pekerjaan profesional dalam layanan publik mungkin (a) mungkin direorganisasi, (b) direstrukturisasi, (c) dipindahkan. Bidang profesional yang semakin Bidang profesional yang semakin terfragmentasi dan tergantung mungkin harus mencari bentuk kontrol baru dan pemahaman baru tentang profesionalisme publik diperlukan.

Berdasarkan beberapa hasil penelitian yang dikemukakan tersebut, maka dapat dimbil kesimpulan bahwa kemampuan, dan profesioanalisme dalam pelayanan publik sangat berhubungan dan mempengaruhi dalam pelayanan public. Meskipun demikian penelitian tentang kemampuan peawai terhadap profesionalisme pelayanan public belum dilakukan secara mendalam. Tujuan penelitian ini adalah menganalisis seberapa besar pengaruh kemampuan pegawai terhadap profesionalisme pelayanan administrsi di Kantor Kecamatan Picung Kabupaten Pandeglang.

\section{METODE PENELITIAN}

Jenis penelitian yang digunakan dalam analisis ini adalah pendekatan kuantitatif. Teknik pengumpulan data penelitian kepustakaan (library research), penelitian lapangan (field work research), yaitu penelitian langsung ke lokasi yang menjadi objek penelitian sebagai berikut : observasi, kuesioner dokumentasi. Tujuannya untuk mengetahui seberaa besar pengaruh kemempaun pegawai terhadap profesionalisme pelayanan administrasi di kantor kecamatan Picung kabupaten Pandeglang. Populasi dalam penelitian ini adalah unsur masyarakat yang datang ke Kantor Kecamatan Picung Kabupaten Pandeglang untuk mengurusi 
Jurnal Administrasi Negara

ISSN : 2598-4039 (Online)

ISSN : 2302-2231 (Print)
Rethorika Berthanila, Sukendar,

Rachmi Yulianti, Indrianti Azhar Firdausi

Universitas Serang Raya kelengkapan adminitrasinya selama periode Bulan Januari 2019, Adapun jumlah masyarakat yang mengunjungi Kantor Kecamatan Picung Kabupaten Pandeglang rata-rata perharinya sebanyak 20 orang. Berdasarkan jumlah hari efektif untuk bulan Juli 2019 adalah 22 hari, maka jumlah populasi adalah 20 x 22 hari adalah 440 oran, teknik sampling yang penulis lakukan adalah teknik proportionate stratified random sampling yaitu teknik pengambilan sampel bila populasi berstrata tetapi kurang proporsional (Sugiyono, 2005 : 93) sebanyak 82 responden.

Teknik analisis data digunakan adalah analisis kuantitatif dengan menganalisi data melalui :

\section{Uji Validitas}

Perhitungan uji validitas dengan menggunakan program SPSS 22 yaitu Korelasi Bivariate Peasrson (Produck Moment Pearson) dan Corrected ItemTotal Correlation. Dengan ketentuan kriteria pengujiannya dengan taraf signifikasi $5 \%$ atau 0,05 yaitu $t_{\text {hitung }} \geq$ $\mathrm{t}_{\text {tabel }}$, maka instrumen peryataanpernyataan kuesioner berkorelasi terhadap skor total dinyatakan valid, dan jika $\mathrm{t}_{\text {hitung }}<\mathrm{t}_{\text {tabel }}$, maka pernyataanpernyataan dalam kuesioner tidak valid.

\section{Uji Reliabilitas}

Dalam menggunakan uji reliabilitas digunakan metode alpa (Cronbach's) dengan bantuan program SPSS 22, dengan ketentuan penilaian alpa (Cronbach's) lebih besar dari pada 0,60 , maka data disebut realibel.

\section{Uji Normalitas}

Setelah data dinyatakan valid dan realibel selanjutnya dilakukan uji normalitas data dengan uji chi square dengan menggunakan alat bantu komputer program SPSS.

Analisis Rata-rata Penafsiran

Untuk mengetahui penafsiran kemampuan pegawai terhadap profesionalisme pelayanan administrasi di Kantor Kecamatan Picung Kabupaten Pandeglang, penulis menggunakan rumus perhitungan dari Sanford Labovitz yang dikutip Bakri Siregar (2000 : 13) yakni sebagai berikut :

$\mathrm{M}=\frac{\sum f(X)}{n}$

Keterangan :

$\mathrm{M}=$ Perolehan angkan penafsiran

$\mathrm{f}=$ Frekuensi

$\mathrm{x}=$ Pembobotan

$\mathrm{n}=$ Jumlah responden

Kemudian nilai rata-rata tersebut di interpretasikan atas lima kriteria dengan menggunakan skala interval 
Jurnal Administrasi Negara

ISSN : 2598-4039 (Online)

ISSN : 2302-2231 (Print)
Rethorika Berthanila, Sukendar,

Rachmi Yulianti, Indrianti Azhar Firdausi

Universitas Serang Raya sebagaimana J. Supranto (2000 : 65) yang mengemukakan sebagai berikut :

Skala Interval $=$ JumlahAlte rnatifJawaban -1

$\overline{\text { JumlahSkalaIntervalYangDiinginkan }}$

$$
\begin{aligned}
& \frac{4-1}{4} \\
& \frac{3}{4}=0.75
\end{aligned}
$$

Maka keempat kriteria penafsiran tersebut diperoleh : jika nilai antara 1,00 - 1.75 berarti kriteria penilaian sangat rendah (Sangat Tidak Baik), jika nilai antara 1,76 - 2.50 berarti kriteria penilaian rendah (Tidak Baik), jika nilai antara 2,51 - 3.25 berarti kriteria penilaian penilaian tinggi (Baik), jika nilai antara 3,26 - 4.00 berarti kriteria penilaian sangat tinggi (Sangat Baik).

\section{Uji Korelasi}

Berdasarkan Sugiyono (2007 : 212) rumus untuk menghitung korelasi pearson product moment adalah sebagai berikut :

$\mathrm{r}_{x y}=\frac{n \sum x_{i} y_{i}-\left(\sum x i\right)\left(\Sigma y_{i}\right)}{\sqrt{\left\{n \Sigma x i^{2}-\left(\sum x_{i}\right)^{2}\right\}\left\{n \Sigma y_{i}^{2}-\left(\Sigma y_{i}\right)^{2}\right\}}}$

Dimana :

$\mathrm{r}_{\mathrm{yx}}=$ Koefieien Korelasi $(\mathrm{X})$ dan $(\mathrm{Y})$

$\mathrm{n}=$ Jumlah sampel yang diteliti

$X=$ Variabel bebas

$\mathrm{Y}=$ Variabel terikat

\section{Regresi Sederhana}

Regresi digunakan untuk memprediksi nilai variabel dependent atau terikat (Y) berdasarkan nilai indepandent atau bebas (X). Teknik regresi sederhana adalah analisis yang digunakan untuk mengetahui pengaruh antar dua variabel atau satu prediktor. Menurut Sugiyono (2007 : 237-239) menyatakan bahwa secara umum persamaan regresi sederhana dirumuskan sebagai berikut :

$$
\begin{aligned}
\hat{Y}=\mathrm{a}+\mathrm{b} X \\
\hat{Y} \quad=\quad \text { Nilai yang diprediksikan } \\
\mathrm{a} \quad=\quad \text { Konstanta atau bila } \mathrm{X}=0 \\
\mathrm{~b} \quad=\quad \text { Koefisien regresi } \\
\mathrm{X} \quad=\quad \text { Nilai variabel independent }
\end{aligned}
$$

Dimana nilai $a$ dan $b$ dapat dicari dengan rumus sebaga berikut :

$$
\mathrm{a}=
$$

$$
\begin{aligned}
& \frac{\left(\sum y\right)\left(\sum x^{2}\right)-\left(\sum x\right)\left(\sum x y\right)}{n \sum x^{2}-\left(\sum x\right)^{2}} \\
& b=\frac{n \sum X Y-\left(\sum x\right)\left(\sum Y\right)}{n \sum X^{2}-\left(\sum X\right)^{2}}
\end{aligned}
$$

\section{Koefisien Determinasi}

Koefisien Determinasi adalah dengan cara mengkuadratkan koefisien yang ditemukan, dimana ditunjukkan dengan rumus sebagai berikut :

$r^{2}=(\mathrm{r})^{2} \times 100$

Keterangan :

$\mathrm{r}^{2}=$ Koefisien determinasi

$\mathrm{r}=$ Koefisien korelasi 
Jurnal Administrasi Negara

ISSN : 2598-4039 (Online)

ISSN : 2302-2231 (Print)
Rethorika Berthanila, Sukendar,

Rachmi Yulianti, Indrianti Azhar Firdausi

Universitas Serang Raya

\section{Uji Signifikansi}

Uji signifikansi adalah suatu cara yang dilakukan untuk menguji signifikansi hubungan. Hubungan ditemukan itu berlaku untuk seluruh populasi. Rumus uji signifikansi adalah sebagai berikut :

$$
t=r s \sqrt{\frac{n-2}{1-r s^{2}}}
$$

Keterangan :

$\mathrm{t}=\mathrm{t}_{\text {hitung }}$

$\mathrm{n}-2=$ derajat kebebasan

$\mathrm{r}=$ Koefisien korelasi

Hasilt $_{\text {hitung }}$ selanjutnya dibandingkan dengan harga $\mathrm{t}_{\text {tabel }}$, Jika $\mathrm{t}_{\text {hitung }}$ jatuh pada daerah penolakan Ho, maka dapat dinyatakan bahwa hipotesis nol yang menyatakan tidak ada pengaruh antara variabel $X$ dan $Y$ adalah ditolak, dan hipotensis alternatif diterima, sehingga hipotesis statistis yang berlaku adalah : $H_{0}: \beta_{s}=0$, berarti variabel $\mathrm{X}$ tidak berpengaruh terhadap variabel $\mathrm{Y}$. $H_{a}: \beta_{s}>0$, berarti variabel $\mathrm{X}$ berpengaruh terhadap variabel $Y$. Untuk menentukan apakah $H_{0}$ diterima atau ditolak, maka penulis menggunkan uji rasio kritis di atas, maka

Jika $\mathrm{t}_{\text {hitung }}>\mathrm{t}_{\text {tabel }}, H_{0}$ ditolak

Jika $\mathrm{t}_{\text {hitung }} \leq \mathrm{t}_{\text {tabel }}, H_{0}$ diterima, (J. Supranto, $2000: 312$ )

\section{HASIL DAN PEMBAHASAN}

Sebelum melakukan analisa data penulis melaukan uji validitas, reliabilitas dan normalitas instrumen dengan hasil sebagai berikut :

\section{Uji Validitas}

Item pertanyaan tentang variabel kemampuan pegawai

Untuk mengetahui apakah angket yang diberikan kepada responden benar-benar dapat mengukur apa yang sedang diukur, maka harus dilakukan pengujian tingkat validitas (kesolihan, validity) jumlah angket yang diterima peneliti sebanyak 9 angket, kemudian angket yang terkumpul diperiksa dan diberi skor kemudian dilanjutkan dengan uji validitas istrumen. Uji validitas yang dihitung dengan menggunakan program Statistical Product and Service Solutions (SPSS) dengan ketentuan kriteria pengujiannya dengan taraf signifikasi $5 \%$ atau 0,05 . Dalam penelitia ini $r$ tabel dari 82 orang responden diperoleh 0,217 dengan ketentuan jika $r$ hitung $\geq \mathrm{r}$ tabel, maka instrumen pernyataan tersebut berkorelasi terhadap skor total dinyatakan valid, jika $\mathrm{r}$ hitung $<\mathrm{r}$ tabel, maka penyataan dalam kuesioner tidak valid. Adapun hasil dari pengujian validitas didapatkan hasil sebagai berikut : 
Jurnal Administrasi Negara ISSN : 2598-4039 (Online)

ISSN : 2302-2231 (Print)
Rethorika Berthanila, Sukendar, Rachmi Yulianti, Indrianti Azhar Firdausi Universitas Serang Raya

Tabel 1

Hasil Uji Validitas Variabel $\mathrm{X}$

\begin{tabular}{ccccc}
\hline No & Pertanyaan Nomor & r hitung & r tabel & Hasil \\
\hline 1 & 1 & 0,409 & 0,217 & Valid \\
\hline 2 & 2 & 0,387 & 0,217 & Valid \\
\hline 3 & 3 & 0,424 & 0,217 & Valid \\
\hline 4 & 4 & 0,536 & 0,217 & Valid \\
\hline 5 & 5 & 0,353 & 0,217 & Valid \\
\hline 6 & 6 & 0,611 & 0,217 & Valid \\
\hline 7 & 7 & 0,495 & 0,217 & Valid \\
\hline 8 & 8 & 0,630 & 0,217 & Valid \\
\hline 9 & 9 & 0,580 & 0,217 & Valid \\
\hline
\end{tabular}

Sumber : Olah Data, 2019

\section{Item pertanyaan tentang variabel Profesionalisme Pelayanan Administrasi}

Adapun hasil dari pengujian validitas variabel profesionalisme pelayanan administrasi $(Y)$ didapatkan hasil sebagai berikut :

Tabel 2

Hasil Uji Validitas Variabel Y

\begin{tabular}{ccccc}
\hline No & Pertanyaan Nomor & r hitung & r tabel & Hasil \\
\hline 1 & 1 & 0,384 & 0,217 & Valid \\
\hline 2 & 2 & 0,361 & 0,217 & Valid \\
\hline 3 & 3 & 0,450 & 0,217 & Valid \\
\hline 4 & 4 & 0,471 & 0,217 & Valid \\
\hline 5 & 5 & 0,514 & 0,217 & Valid \\
\hline 6 & 6 & 0,373 & 0,217 & Valid \\
\hline 7 & 7 & 0,569 & 0,217 & Valid \\
\hline 8 & 8 & 0,536 & 0,217 & Valid \\
\hline 9 & 9 & 0,674 & 0,217 & Valid \\
\hline
\end{tabular}

Sumber : Olah Data, 2019

Tabel 4.3 dan 4.4 menunjukkan bahwa semua indikator yang digunakan untuk mengukur variabel $\mathrm{X}$ dalam penelitian ini mempunyai nilai korelasi yang lebih besar dari 0,217, sehingga 
Jurnal Administrasi Negara

ISSN : 2598-4039 (Online)

ISSN : 2302-2231 (Print)
Rethorika Berthanila, Sukendar, Rachmi Yulianti, Indrianti Azhar Firdausi Universitas Serang Raya dengan demikian semua indikator dalam variabel $X$ adalah valid.

\section{Uji Reliabilitas}

Pengujian reliabilitas dilakukan dengan internal consistency dengan Teknik Belah Dua (split half) yang dianalisis dengan rumus Spearman Brown.

$$
r_{i}=\frac{2 \cdot r_{b}}{1+r_{b}}
$$

Hasil rangkuman dari perhitungan tersebut di atas, dapat dilihat dalam tabel berikut ini :

Tabel 3

Rangkuman Hasil Perhitungan Reliabilitas Instrumen

\begin{tabular}{lcccc}
\hline \multicolumn{1}{c}{ Variabel } & $\begin{array}{c}\text { Koefisien } \\
\text { Korelasi } \\
\left(\mathbf{r}_{\text {tt }}\right)\end{array}$ & $\begin{array}{c}\text { Harg } \\
\mathbf{a} \\
(\mathbf{r} \text { tot })\end{array}$ & r tabel & Hasil \\
\hline Kemampuan pegawai & 0.440 & 0.611 & 0.217 & Reliabel \\
Profesionalisme & 0.281 & 0.439 & 0.217 & Reliabel \\
pelayanan & & & & \\
administrasi & & & & \\
\hline
\end{tabular}

Sumber : Olah Data, 2019

Dari tabel di atas dapat dilihat bahwa hasil; perhitungan reliabilitas menunjukkan bahwa semua instrumen penelitian reliabel dan dapat diandalkan.

\section{Uji Normalitas}

Uji kenormalan data kemampuan pegawai dan profesionalisme pelayanan administrasi, masing-masing dilakukan dengan SPSS Uji Chi-Square terhadap 82 responden yang didistribusikan sebaran datanya dengan interval kelas didasarkan pada kurva normal. persyaratan hipotesis tabel yang digunakan adalah :

$\mathrm{H}_{\mathrm{o}}$ : Data populasi tidak berdistribusi normal

$\mathrm{H}_{1}$ : Data populasi berdistribusi normal

Adapun taraf signifikansi yang digunakan sebagai dasar penolakan atau penerimaan keputusan normal atau tidaknya suatu distribusi data adalah taraf signifikansi lima persen. Adapun hasil perhitungan program SPSS dapat dilihat pada tabel berikut ini: 
Jurnal Administrasi Negara

ISSN : 2598-4039 (Online)

ISSN : 2302-2231 (Print)
Rethorika Berthanila, Sukendar, Rachmi Yulianti, Indrianti Azhar Firdausi

Universitas Serang Raya

Tabel 4

Uji Chi-Square Variabel

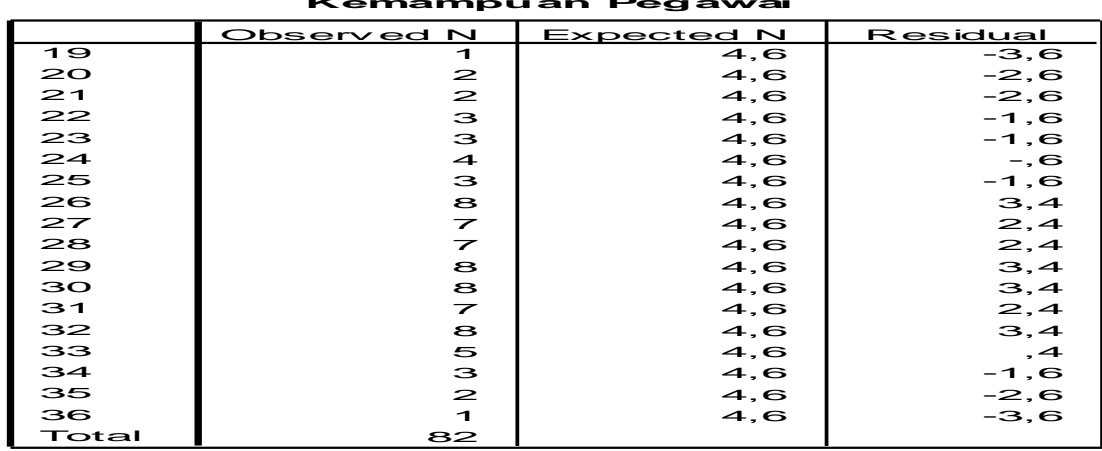

Sumber : Hasil Perhitungan SPSS, 2019.

Tabel 5

Uji Chi-Square Variabel

Profesionalisme Pelayanan

\begin{tabular}{|l|r|r|r|}
\hline & Observed $N$ & Expected $N$ & Residual \\
\hline 16 & 1 & 5,5 & $-4,5$ \\
20 & 3 & 5,5 & $-2,5$ \\
23 & 4 & 5,5 & $-1,5$ \\
24 & 5 & 5,5 &,- 5 \\
25 & 7 & 5,5 & 1,5 \\
26 & 6 & 5,5 &, 5 \\
27 & 6 & 5,5 &, 5 \\
28 & 6 & 5,5 &, 5 \\
29 & 7 & 5,5 & 1,5 \\
30 & 13 & 5,5 & 7,5 \\
31 & 9 & 5,5 & 3,5 \\
32 & 6 & 5,5 &, 5 \\
33 & 4 & 5,5 & $-1,5$ \\
34 & 3 & 5,5 & $-2,5$ \\
35 & 2 & 5,5 & $-3,5$ \\
Total & 82 & & \\
\hline
\end{tabular}

Sumber : Hasil Perhitungan SPSS, 2019 
Jurnal Administrasi Negara

ISSN : 2598-4039 (Online)

ISSN : 2302-2231 (Print)
Rethorika Berthanila, Sukendar,

Rachmi Yulianti, Indrianti Azhar Firdausi

Universitas Serang Raya
Tabel 6

Uji Normalitas Variabel Kemampuan

Pegawai dan Profesionalisme Pelayanan Administrasi

\begin{tabular}{|l|r|r|}
\hline \multicolumn{1}{|c}{ Test Statistics } \\
\hline & $\begin{array}{c}\text { Kemampuan } \\
\text { Pegawai }\end{array}$ & $\begin{array}{c}\text { Prof esiona } \\
\text { lisme } \\
\text { Pelay anan }\end{array}$ \\
\hline Chi-Square $a, b$ & 26,439 & 22,634 \\
df & 17 & 14 \\
Asy mp. Sig. &, 067 &, 066 \\
\hline
\end{tabular}

a. 18 cells $(100,0 \%)$ have expected f requencies less than 5 . The minimum expected cell f requency is 4,6 .

b. 0 cells $(, 0 \%)$ hav e expected frequencies less than 5 . The minimum expected cell frequency is 5,5 .

Hasil perhitungan uji kenormalan data, dapat dilihat pada tabel berikut :

Tabel 7

\section{Rangkuman Analisis Uji} Kenormalan Uji Chi Square

\begin{tabular}{|c|l|c|c|c|}
\multicolumn{5}{c|}{$\mathrm{n}=82$} \\
\hline No & \multicolumn{1}{|c|}{ Variabel } & X2hitung & X2tabel & Ket \\
\hline 1 & Kemampuan & 26.439 & 27.590 & Normal \\
2 & $\begin{array}{l}\text { pegawai } \\
\text { Profesionalisme } \\
\text { pelayanan } \\
\text { administrasi }\end{array}$ & 22.634 & 23.680 & Normal \\
\hline
\end{tabular}

Sumber : Penelitian, 2019

Berdasarkan pada tabel di atas dapat dilihat bahwa $X^{2}$ hitung berada di atas 0,05. Hal ini menunjukkan bahwa persyaratan yang diajukan dapat diterima, yaitu data populasi berdistribusi normal. Dengan persyaratan data berasal dari populasi yang berdistribusi normal terpenuhi pada $\alpha=0,05$. a. Uji Normalitas $(n=82)$ Uji Galat Taksiran X

Dari hasil perhitungan diperoleh $\mathrm{X}^{2}$ hitung 26.439 dengan $\mathrm{n}=82$ dan taraf nyata $\alpha=0,05$, didapat $X^{2}$ tabel 27,590 . Jadi $X^{2}$ hitung $26.439<X^{2}$ tabel 27,590; maka dengan ini Ho diterima yang berarti bahwa sampel berdistribusi normal.

b. Uji Normalitas $(n=82)$ Uji Galat Taksiran Y

Dari hasil perhitungan diperoleh $\mathrm{X}^{2}$ hitung 22.634 dengan $\mathrm{n}=82$ dan taraf nyata $\alpha=0,05$, didapat $X^{2}$ tabel 23.680 . Jadi $\mathrm{X}^{2}$ hitung $22.634<\mathrm{X}^{2}$ tabel 23.680; maka dengan ini Ho diterima yang berarti bahwa sampel berdistribusi normal.

\section{Deskripsi Data}

Dari hasil analisis dan pembobotan nilai jawaban tiap lembar angket. Selanjutnya skor tersebut dihitung dengan menggunakan alat bantu komputer SPSS. Data statistik yang dibutuhkan sebagai bahan analisis meliputi data minimal, data maksimal, mean, median, modus, standar deviasi, dan varians. Untuk lebih jelasnya mengenai hasil deskripsi kedua variabel tersebut dapat dilihat pada tabel berikut ini : 


\section{Tabel 8}

Deskripsi Data Keseluruhan Variabel

Descriptive Statistics

\begin{tabular}{|c|c|c|c|c|c|c|c|c|c|}
\hline & $\mathrm{N}$ & Range & Minimum & Maximum & Sum & \multicolumn{2}{|c|}{ Mean } & Std. & Variance \\
\hline & Statistic & Statistic & Statistic & Statistic & Statistic & Statistic & Std. Error & Statistic & Statistic \\
\hline Kemampuan Pegawai & 82 & 17 & 19 & 36 & 2318 & 28,27 &, 432 & 3,913 & 15,310 \\
\hline $\begin{array}{l}\text { Prof esionalisme } \\
\text { Pelay anan }\end{array}$ & 82 & 19 & 16 & 35 & 2317 & 28,26 & 415 & 3,761 & 14,143 \\
\hline Valid N (listwise) & 82 & & & & & & & & \\
\hline
\end{tabular}

Sumber : Hasil Perhitungan SPSS, 2019

Secara singkat deskripsi data yang dimaksudkan menyangkut skor terendah dan skor tertinggi yang secara empiris dicapai oleh kedua variabel tersebut, sehingga akan nampak rentang datanya. Selain itu juga dideskripsikan variabelitas yang menyangkut nilai ratarata (Mean), Standar Deviasi (SD). Berikut ini secara berurutan disajikan menurut jenis data masing-masing, yaitu :

\section{Kemampuan pegawai}

Indikator variabel kemampuan pegawai sebanyak 9 pertanyaan. Dari hasil perhitungan diketahui bahwa skor terendah 19 dan sekor tertinggi 36. Dengan demikian rentang skor yang ada adalah 17 (36-19). Bila dilihat dari angka tersebut, maka angka minimum yang mungkin dapat dicapai adalah 9 sedangkan angka maksimum yang mungkin bisa dicapai adalah 36, nilai rata-rata mencapai 28,27; dan standar deviasinya 3.913

Berdasarkan rentang skor yang ada, maka data dapat dideskripsikan ke dalam distribusi skor data kemampuan pegawai tersebut secara ringkas dapat disajikan pada tabel berikut. 
Jurnal Administrasi Negara

ISSN : 2598-4039 (Online)

ISSN : 2302-2231 (Print)
Rethorika Berthanila, Sukendar, Rachmi Yulianti, Indrianti Azhar Firdausi

Universitas Serang Raya

Tabel 9

Distribusi Frekuensi Skor Variabel

\begin{tabular}{|c|c|c|c|c|c|}
\hline \multicolumn{6}{|c|}{ Kemampuan Pegawai } \\
\hline & & Frequency & Percent & Valid Percent & $\begin{array}{c}\text { Cumulat iv e } \\
\text { Percent }\end{array}$ \\
\hline \multirow[t]{19}{*}{ Valid } & 19 & 1 & 1,2 & 1,2 & 1,2 \\
\hline & 20 & 2 & 2,4 & 2,4 & 3,7 \\
\hline & 21 & 2 & 2,4 & 2,4 & 6,1 \\
\hline & 22 & 3 & 3,7 & 3,7 & 9,8 \\
\hline & 23 & 3 & 3,7 & 3,7 & 13,4 \\
\hline & 24 & 4 & 4,9 & 4,9 & 18,3 \\
\hline & 25 & 3 & 3,7 & 3,7 & 22,0 \\
\hline & 26 & 8 & 9,8 & 9,8 & 31,7 \\
\hline & 27 & 7 & 8,5 & 8,5 & 40,2 \\
\hline & 28 & 7 & 8,5 & 8,5 & 48,8 \\
\hline & 29 & 8 & 9,8 & 9,8 & 58,5 \\
\hline & 30 & 8 & 9,8 & 9,8 & 68,3 \\
\hline & 31 & 7 & 8,5 & 8,5 & 76,8 \\
\hline & 32 & 8 & 9,8 & 9,8 & 86,6 \\
\hline & 33 & 5 & 6,1 & 6,1 & 92,7 \\
\hline & 34 & 3 & 3,7 & 3,7 & 96,3 \\
\hline & 35 & 2 & 2,4 & 2,4 & 98,8 \\
\hline & 36 & 1 & 1,2 & 1,2 & 100,0 \\
\hline & Total & 82 & 100,0 & 100,0 & \\
\hline
\end{tabular}

Sumber : Hasil Perhitungan SPSS, 2019

Dari data distribusi frekuensi skor variabel kemampuan pegawai di atas, maka dapat dibuat grafik sebaran data tersebut seperti gambar berikut:

Kemampuan Pegawai

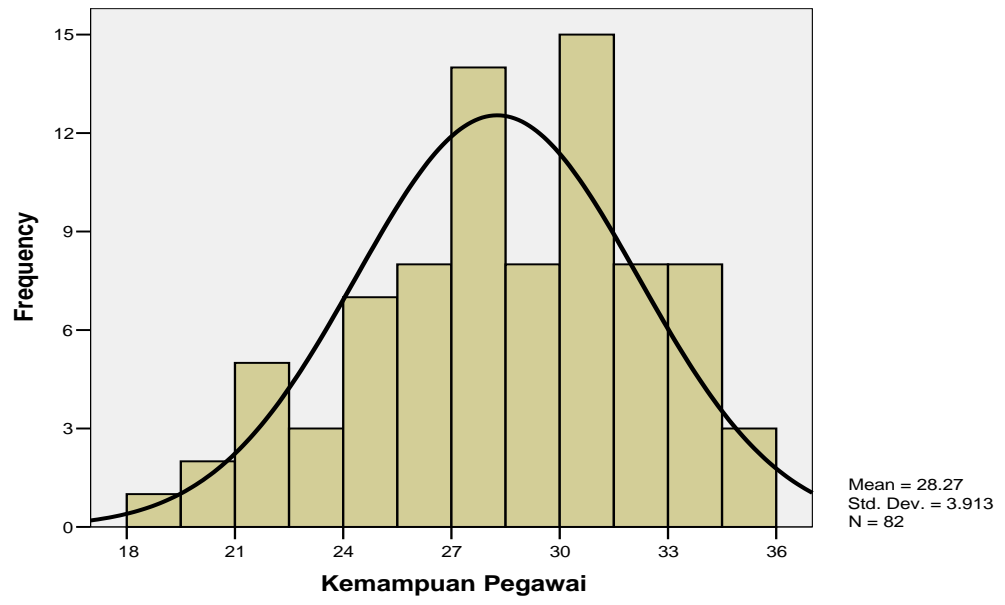

Gambar 4.1 : Variabel Kemampuan Pegawai 
Jurnal Administrasi Negara

ISSN : 2598-4039 (Online)

ISSN : 2302-2231 (Print)
Rethorika Berthanila, Sukendar, Rachmi Yulianti, Indrianti Azhar Firdausi Universitas Serang Raya
Profesionalisme

\section{Administrasi}

Skor

data

variabel

profesionalisme pelayanan administrasi dimana jumlah pertanyaan sebanyak 9 pertanyaan. Dari hasil perhitungan diketahui bahwa skor terendah 16 dan sekor tertinggi 35. Dengan demikian rentang skor yang ada adalah 19 (35-16). Bila dilihat dari angket tersebut, maka angka minimum yang mungkin dapat

Tabel 10

\section{Distribusi Frekuensi Skor Variabel}

Profesionalisme Pelayanan

\begin{tabular}{|ll|r|r|r|r|}
\hline & & & & \multicolumn{2}{c|}{$\begin{array}{c}\text { Cumulativ } \\
\text { Percent }\end{array}$} \\
\hline Valid & 16 & Frequency & Percent & Valid Percent & 1,2 \\
& 20 & 1 & 1,2 & 1,2 & 4,9 \\
& 3 & 3,7 & 3,7 & 9,8 \\
& 4 & 4,9 & 4,9 & 15,9 \\
& 4 & 5 & 6,1 & 6,1 & 24,4 \\
25 & 7 & 8,5 & 8,5 & 31,7 \\
26 & 6 & 7,3 & 7,3 & 39,0 \\
27 & 6 & 7,3 & 7,3 & 46,3 \\
28 & 6 & 7,3 & 7,3 & 54,9 \\
29 & 7 & 8,5 & 8,5 & 70,7 \\
30 & 13 & 15,9 & 15,9 & 81,7 \\
31 & 9 & 11,0 & 11,0 & 89,0 \\
32 & 6 & 7,3 & 7,3 & 93,9 \\
33 & 4 & 4,9 & 4,9 & 97,6 \\
34 & 3 & 3,7 & 3,7 & 100,0 \\
35 & 2 & 2,4 & 2,4 & \\
Total & 82 & 100,0 & 100,0 & \\
\hline
\end{tabular}

Sumber : Hasil Perhitungan SPSS, 2019 dicapai adalah 9 sedangkan angka maksimum yang mungkin bisa dicapai adalah 36, nilai rata-rata mencapai 28,26; dan standar deviasinya 3.761 . Berdasarkan rentang skor yang ada, maka data dapat dideskripsikan ke dalam distribusi skor data profesionalisme pelayanan administrasi tersebut secara ringkas dapat disajikan pada tabel berikut. 
Berdasarkan data distribusi dapat dibuat grafik sebaran data frekuensi skor variabel profesionalisme tersebut seperti gambar berikut : pelayanan administrasi di atas, maka

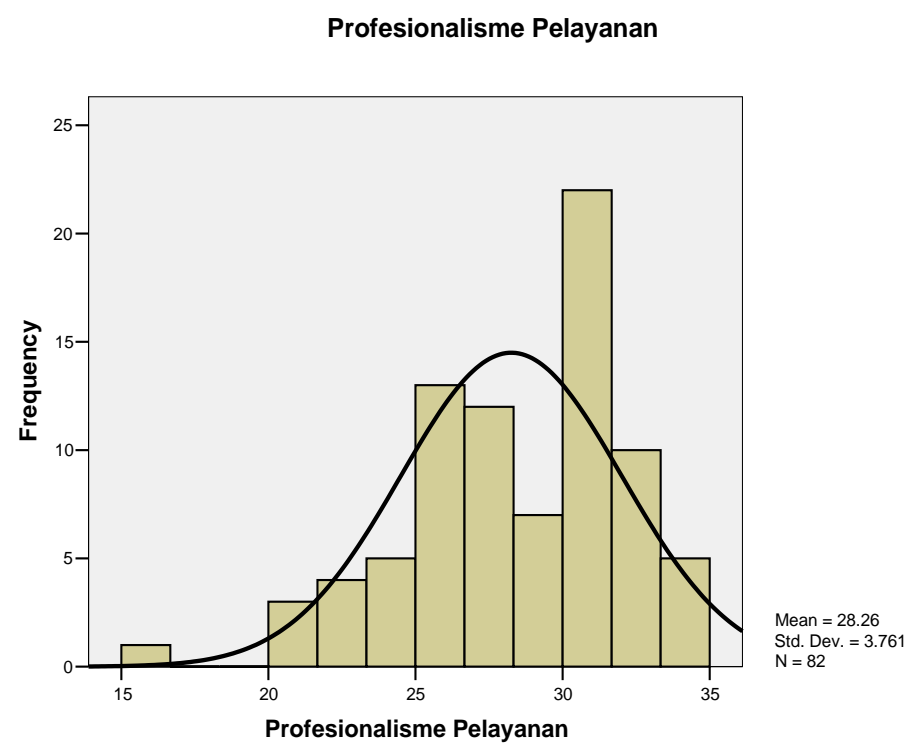

Gambar 4.2 : Profesionalisme pelayanan administrasi

\section{Analisis Data}

Setelah dilakukan pembahasan pada setiap pernyataan-pernyatan indikator kemampuan pegawai, maka selanjutnya akan direkapitulasi guna mengetahui rata-rata jawaban responden mengenai kemampuan pegawai. Untuk lebih jelasnya dapat dilihat pada tabel berikut ini :

Tabel 11

Rekapitulasi Variabel X (Kemampuan pegawai)

\begin{tabular}{cccc}
\hline No & Pernyataan & Penafsiran & Kriteria \\
\hline 1 & Item $\times 1$ & 3.20 & Baik \\
\hline 2 & Item $\times 2$ & 3.16 & Baik \\
\hline 3 & Item $\times 3$ & 2.99 & Baik \\
\hline 4 & Item $\times 4$ & 3.28 & Sangat Baik \\
\hline 5 & Item $\times 5$ & 3.21 & Baik \\
\hline 6 & Item $\times 6$ & 3.10 & Baik \\
\hline
\end{tabular}


Jurnal Administrasi Negara

ISSN : 2598-4039 (Online)

ISSN : 2302-2231 (Print)
Rethorika Berthanila, Sukendar, Rachmi Yulianti, Indrianti Azhar Firdausi

Universitas Serang Raya

\begin{tabular}{cccc}
\hline 7 & Item $\times 7$ & 3.11 & Baik \\
\hline 8 & Item $\times 8$ & 3.13 & Baik \\
\hline 9 & Item $\times 9$ & 3.10 & Baik \\
\hline & Jumlah & 28.29 & - \\
\hline & Rata-rata & 3.14 & Baik \\
\hline
\end{tabular}

Sumber : Penelitian, 2019

Dari hasil rekapitulasi pada tabel diatas, dapat diketahui bahwa rata-rata tanggapan responden terhadap item pernyataan yang terkait dengan variabel $X$ didapatkan angka rata-rata penafsiran sebesar 3,14. Hal ini menunjukkan kriteria baik. Hal ini berarti bahwa kemampuan pegawai di Kantor Kecamatan Picung Kabupaten Pandeglang sudah baik dan sesuai dengan yang dibutuhkan.
Setelah dilakukan pembahasan pada setiap pernyataan-pernyatan indikator profesionalisme pelayanan administrasi, maka selanjutnya akan direkapitulasi guna mengetahui ratarata jawaban responden mengenai kemampuan pegawai. Untuk lebih jelasnya dapat dilihat pada tabel berikut ini:

\section{Tabel 12}

Rekapitulasi Variabel Y (Profesionalisme pelayanan administrasi)

\begin{tabular}{cccc}
\hline No & Pernyataan & Penafsiran & Kriteria \\
\hline 1 & Item y1 & 3.15 & Baik \\
2 & Item y2 & 3.07 & Baik \\
3 & Item y3 & 3.06 & Baik \\
4 & Item y4 & 2.99 & Baik \\
5 & Item y5 & 3.16 & Baik \\
6 & Item y6 & 3.12 & Baik \\
7 & Item y7 & 3.29 & Sangat Baik \\
8 & Item y8 & 3.10 & Baik \\
9 & Item y9 & 3.32 & Sangat Baik \\
& Jumlah & 28.26 & - \\
& Rata-rata & 3.14 & Baik \\
\hline
\end{tabular}

Sumber : Penelitian, 2013

Dari hasil rekapitulasi pada tabel diatas, dapat diketahui bahwa rata-rata tanggapan responden terhadap item pernyataan yang terkait dengan variabel 
Jurnal Administrasi Negara

ISSN : 2598-4039 (Online)

ISSN : 2302-2231 (Print)
Rethorika Berthanila, Sukendar, Rachmi Yulianti, Indrianti Azhar Firdausi Universitas Serang Raya profesionalisme pelayanan administrasi didapatkan angka rata-rata penafsiran sebesar 3,14 ini menunjukkan kriteria baik. Hal ini berarti bahwa profesionalisme pelayanan administrasi di Kantor Kecamatan Picung Kabupaten Pandeglang sudah baik.

\section{Analisis Korelasi Produk Moment}

Untuk mengetahui sejauhmana pengaruh kemampuan pegawai terhadap profesionalisme pelayanan administrasi di Kantor Kecamatan Picung Kabupaten Pandeglang, maka langkah selanjutnya dilakukan analisa korelasi dengan menggunakan korelasi produk moment, aapun perhitungannya sebagai berikut :

$$
\mathrm{r}^{x y}=\frac{n \sum x_{i} y_{i}-(\Sigma x i)\left(\Sigma y_{i}\right)}{\sqrt{\left\{n \Sigma x i^{2}-\left(\Sigma x_{i}\right)^{2}\right\}\left\{n \Sigma y_{i}^{2}-\left(\Sigma y_{i}\right)^{2}\right\}}}
$$

Berdasarkan rumus tersebut diperoleh hasil pada tabel berikut ini :

Tabel 13

Analsisi Korelasi Product Moment

Model Summary

\begin{tabular}{|l|r|r|r|r|}
\hline Model & $\mathrm{R}$ & $\mathrm{R}$ Square & $\begin{array}{c}\text { Adjusted } \\
\text { R Square }\end{array}$ & $\begin{array}{c}\text { Std. Error of } \\
\text { the Estimate }\end{array}$ \\
\hline 1 &, $608^{\mathrm{a}}$ &, 369 &, 361 & 3,005 \\
\hline
\end{tabular}

a. Predictors: (Constant), Kemampuan Pegawai

Sumber: Olah Data SPSS, 2019.

Berdasarkan perhitungan SPSS di atas, koefisien korelasi (r) antara kemampuan pegawai terhadap profesionalisme pelayanan administrasi adalah sebesar $\mathbf{0 , 6 0 8}$, berdasarkan tabel interpretasi koefisien korelasi 0,562 berada pada interval 0,60 - 0799 dengan tingkat pengaruh kuat. Ini berarti bahwa ada pengaruh kuat antara kemampuan pegawai terhadap profesionalisme pelayanan administrasi di Kantor Kecamatan Picung Kabupaten Pandeglang.

\section{Analisis Regresi Linier Sederhana}

Persamaan regresi ini digunakan untuk melakukan prediksi seberapa besar nilai variabel profesionalisme pelayanan administrasi apabila nilai variabel kemampuan pegawai dimanipulasi (dirubah-rubah). Secara umum persamaan regresi sederhana 
Jurnal Administrasi Negara

ISSN : 2598-4039 (Online)

ISSN : 2302-2231 (Print)
Rethorika Berthanila, Sukendar, Rachmi Yulianti, Indrianti Azhar Firdausi Universitas Serang Raya (dengan satu prediktor) dapat dirumuskan sebagai berikut:

$$
\mathrm{Y}=\mathrm{a}+\mathrm{bX}
$$

Berdasarkan rumus di atas untuk dapat menentukan persamaan regresi maka terlebih dahulu harus ditentukan harga a dan $b$ dengan mengunakan rumus perhitungan sebagai berikut:

$$
\begin{aligned}
& \mathrm{a}=\frac{\left(\sum y\right)\left(\sum x^{2}\right)-\left(\sum x\right)\left(\sum x y\right)}{n \sum x^{2}-\left(\sum x\right)^{2}} \\
& b=\frac{n \sum X Y-\left(\sum X\right)\left(\sum Y\right)}{n \sum X^{2}-\left(\sum X\right)^{2}}
\end{aligned}
$$

Berdasarkan perhitungan program SPSS diperoleh hasil sebagaimana terlihat pada tabel berikut ini

Tabel 14

\section{Analsisi Persamaan Regresi Variabel Kemampuan Pegawai Terhadap Profesionalisme Pelayanan Administrasi}

Coefficients ${ }^{a}$

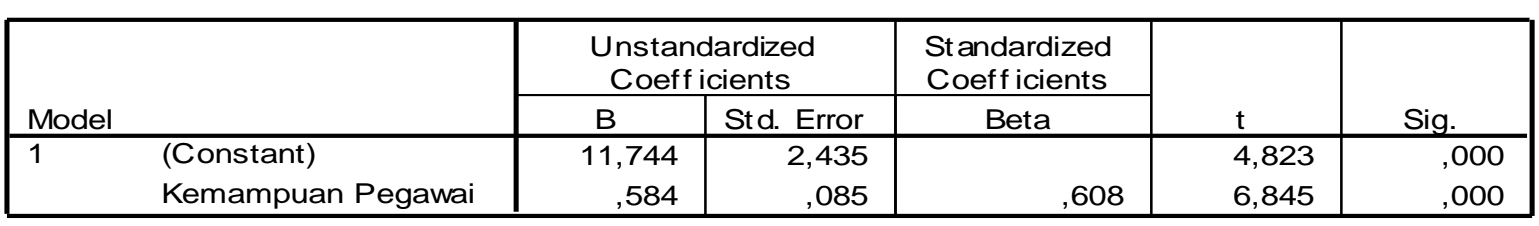

a. Dependent Variable: Prof esionalisme Pelay anan

Sumber : Olah Data SPSS, 2019

Berdasarkan harga a dan $b$ melalui perhitungan SPSS pada tabel di atas maka persamaan regresi kemampuan pegawai dan profesionalisme pelayanan administrasi adalah sebagai berikut:

$$
\hat{Y}=\mathbf{1 1}, 744+0,584 \mathrm{X}
$$

Hal ini berarti bahwa setiap peningkatan 1 skor variabel kemampuan pegawai Kecamatan Picung Kabupaten Pandeglang, maka skor profesionalisme pelayanan administrasi meningkat sebesar 0,584 .

\section{Analisis Koefisien Determinasi}

Berdasarkan rumus keofisien determinasi maka dapat dihitung sebagai berikut :

$$
\begin{aligned}
r^{2} & =r^{2} \times 100 \% \\
& =(0,608)^{2} \times 100 \% \\
& =\mathbf{3 6}, \mathbf{9} \%
\end{aligned}
$$

Dari perhitungan koefisien penentu/keofisien determinasi sebesar 36,90. Hal ini berarti bahwa kemampuan pegawai memberi kontribusi $\quad 36,9 \% \quad$ terhadap profesionalisme pelayanan administrasi, sedangkan sisanya sebesar $63,1 \%$ merupakan faktor lain yang tidak 
Jurnal Administrasi Negara

ISSN : 2598-4039 (Online)

ISSN : 2302-2231 (Print)
Rethorika Berthanila, Sukendar,

Rachmi Yulianti, Indrianti Azhar Firdausi

Universitas Serang Raya ditinjau dalam penelitian ini yang ikut serta mempengaruhi profesionalisme pelayanan administrasi yang perlu dilakukan penelitian lebih lanjut.

\section{Uji Hipotesis}

Untuk mengetahui signifikansi koefisien korelasi pengaruh kemampuan pegawai terhadap profesionalisme pelayanan administrasi di Kantor Kecamatan Picung Kabupaten Pandeglang dilakukan dengan uji hipotesis sebaga berikut :

$$
\begin{aligned}
& \mathrm{t}=\frac{r s \sqrt{n-2}}{\sqrt{1-r^{2}}} \\
& t=\frac{0.608 \sqrt{82-2}}{\sqrt{1-0.608}} \\
& t=\frac{0.608 * 8.94427191}{\sqrt{1-0.3693}} \\
& t=\frac{5.4357}{0.7941} \\
& t=6.845
\end{aligned}
$$

Dari perhitungan uji hipotesis di atas, diperoleh thitung sebesar 6,845. Kemudian untuk mengetahui signifikansi koefisien korelasi, maka dikonsultasikan terhadap nilai ttabel dengan taraf kesalahan 0,05\% dan $\mathrm{dk}$ (derajak kebebasan) n-2, yaitu $82-2=$ 80, sehingga diperoleh nilai tabel sebesar 1,664. Dengan demikian thitung lebih besar dari ttabel, yaitu 6,845>1,664. Berdasarkan hasil tersebut Ho : $\varrho=0$ ditolak dan $\mathrm{Ha}: \varrho \neq 0$ diterima, yang berarti bahwa terdapat pengaruh antara kemampuan pegawai terhadap profesionalisme pelayanan administrasi.

Berdasarkan hasil perhitungan koefsien korelasi antara variabel $X$ dan $Y$ diperoleh nilai sebesar 0,608. Berdasarkan interval berada pada interval 0,60 - 0799 dengan tingkat pengaruh kuat. Ini berarti bahwa ada pengaruh yang kuat antara kemampuan pegawai terhadap profesionalisme pelayanan administrasi di Kantor Kecamatan Picung Kabupaten Pandeglang.

Sedangkan berdasarkan perhitungan regresi linier menurut SPSS diperoleh a (konstanta) adalah 17,744 dan b (koefisien regresi) sebesar 0,584, sehingga diperoleh persamaan regresi liniernya sebagai berikut :

$$
\begin{aligned}
& Y=a+b x \\
& Y=11,744+0,584 x
\end{aligned}
$$

\section{Hal ini berarti bahwa setiap peningkatan 1 skor variabel kemampuan pegawai, maka skor profesionalisme pelayanan administrasi meningkat sebesar 0,584 .}

\section{Adapun nilai koefisien} determinasi diperoleh $\left(\mathrm{r}^{2}\right)$ sebesar 0.369. Hal ini dapat diartikan bahwa kemampuan pegawai memberi kontribusi $\quad 36,9 \% \quad$ terhadap profesionalisme pelayanan administrasi, 
Jurnal Administrasi Negara

ISSN : 2598-4039 (Online)

ISSN : 2302-2231 (Print)
Rethorika Berthanila, Sukendar,

Rachmi Yulianti, Indrianti Azhar Firdausi

Universitas Serang Raya sedangkan sisanya sebesar 63,1\% merupakan faktor lain yang tidak ditinjau dalam penelitian ini yang ikut serta mempengaruhi profesionalisme pelayanan administrasi yang perlu dilakukan penelitian lebih lanjut.

Dari perhitungan uji hipotesis diperoleh thitung sebesar 6,845. Kemudian untuk mengetahui signifikansi koefisien korelasi, maka dikonsultasikan terhadap nilai tabel dengan taraf kesalahan 0,05\% dan $\mathrm{dk}$ (derajak kebebasan) n-2, yaitu $82-2=80$, sehingga diperoleh nilai tabel sebesar 1,664. Dengan demikian thitung lebih besar dari tabel, yaitu 6,845>1,664. Berdasarkan hasil tersebut Ho : $\varrho=0$ ditolak dan Ha : @ $\neq 0$ diterima, yang berarti bahwa terdapat pengaruh antara kemampuan pegawai terhadap profesionalisme pelayanan administrasi.

\section{PENUTUP}

\section{SIMPULAN DAN SARAN}

Berdasarkan hasil analsis kemampuan pegawai terhadap profesionalisme pelayanan administrasi di Kantor Kecamatan Picung Kabupaten Pandeglang mempunyai pengaruh yang kuat dan bernilai positif terhadap profesioalisme pelayanan administrasi, Hal ini terbukti dengan hasil perolehan angka rata-rata penafsiran jawaban responden 3.14 dimana nilai tersebut masuk dalam kriteria tinggi/baik.
Sedangkan dari hasil rekapitulasi perolehan angka penafsiran variabel profesionalisme pelayanan administrasi di Kantor Kecamatan Picung Kabupaten Pandeglang diperoleh rata-rata angka penafsiran sebesar 3.14, dan kriteria ini menunjukkan kriteria tinggi/ baik. Korelasi sebesar 0,608, regresi sebesar 0,584. Hal ini berarti bahwa setiap peningkatan 1 skor variabel kemampuan pegawai, maka skor profesionalisme pelayanan administrasi di Kantor Kecamatan Picung Kabupaten Pandeglang meningkat sebesar 0,584. Sedangkan kontribusi kemampuan pegawai terhadap profesionalisme pelayanan administrasi di Kantor Kecamatan Picung Kabupaten Pandeglang sebesar 36,9\%, hasil uji signifikansi korelasi dengan menggunakan uji $\mathrm{t}$ hipotesis, diketahui thitung lebih besar dari tabel, yaitu 6,845 > 1,664. Hal ini berarti Ho : $\mathrm{Q}=0$ ditolak dan Ha : $\varrho \neq 0$ diterima, yang berarti bahwa terdapat pengaruh antara kemampuan pegawai terhadap profesionalisme pelayanan administrasi di Kantor Kecamatan Picung Kabupaten Pandeglang.

Adapun saran yang diberikan yaitu untuk meningkatakn kemampuan pegawai di Kantor Kecamatan Picung Kabupaten Pandeglang, perlu diberikan pelatihan dan bimbingan mengenai pelayanan administrasi yang baik dan 
Jurnal Administrasi Negara

ISSN : 2598-4039 (Online)

ISSN : 2302-2231 (Print)
Rethorika Berthanila, Sukendar,

Rachmi Yulianti, Indrianti Azhar Firdausi

Universitas Serang Raya benar, kemudian diberikan kesempatan untuk ikut serta dalam pelatihanpelatihan baik yang diadakan instansi pemerintah terkait maupun organisasi swasta lainnya, dan juga bisa dengan meberikan ijin belajar kepada para pegawai yang akan melanjutkan pendidikan ke jenjang yang lebih tinggi lagi. Untuk meningkatkan profesionalisme pelayanan administrasi selain memberikan bimbingan yang memadai juga dengan melaksanakan pengawasan terhadap semua aktivitas kerja yang dilaksanakan oleh bawahannya, khusunya terhadap pegawai yang bekerja dalam pelayanan, sehingga dengan diadakannya pengawasan yang ketat, akan berdampak kepada keprofesionalan pegawai dalam bekerja.

\section{REFERENSI}

Atmosudirjo (2004) Dasar-dasar Administrasi Manajemen Dan. Manajemen Kantor, Jakarta: Gunung Agung

Darwin, E. (2015). Profesionalisme Aparatur Dalam Pelayanan Publik Di Kantor Kecamatan Sario1. Jurnal Politico, 2(6), 1-10.

Fandy Tjiptono (2002) Prinsip-Prinsip Total Quality Service. Penerbit Andi. Jakarta

H. A. S. Moenir (2005) Manajamen Pelayanan Umum di Indonesesi, Ghalia Indonesia. Jakarta

Handoko, T. Hani, (2000) Manajemen Personalia dan Sumber Daya Manusia. BPFE, Yogyakarta.

Hariandja, M.T.E. (2002) Manajemen Sumber Daya Manusia. Grasindo. Jakarta.

Hasibuan, SP. Malayu. Manajemen Sumber Daya Manusia. Edisi Revisi. Bumi Aksara. Jakarta

Mandasari, A. (2014). Kegunaan Penelitian.4(2), 1148-1158. 
Jurnal Administrasi Negara

ISSN : 2598-4039 (Online)

ISSN : 2302-2231 (Print)
Rethorika Berthanila, Sukendar,

Rachmi Yulianti, Indrianti Azhar Firdausi

Universitas Serang Raya
Mandey, D., Mandey, J., \& Tulusan, F. (2015). Pengaruh Profesionalisme Aparat Kelurahan Terhadap Kualitas Pelayanan Publik Di Kelurahan Malalayang Satu Kecamatan Malalayang Kota Manado. Jurnal Administrasi Publik UNSRAT, 3(031), 1373.

Mariana, D. P. (2016). PROFESIONALISME APARAT DAN KAPASITAS Jurnal Ilmu Pemerintahan. Ilmu Pemerintahan, 2(2).

Mangkunegara, Anwar Prabu. (2000) Manajemen Sumber Daya Manusia Perusahaan. PT.Remaja Rosdakarya. Bandung.

Miftah Thoha, (2001) Perilaku Organisasi, Konsep Dasar Dan Aplikasinya. Djambatan. Bandung

Noordegraaf, M. (2016). Reconfiguring Professional Work: Changing Forms of Professionalism in Public Services. Administration and Society, 48(7), 783-810. https://doi.org/ 10.1177/0095399713509242

Robbins, P.S. (2008) Prinsip-prinsip Perlaku Organisasi. Edisi kelima. Penerbit Erlangga. Jakarta
Soewarno Handayaningrat., (2003) Pengantar Studi Ilmu Administrasi dan Manajemen Edisi Revisi. PT. Gunung Agung. Jakarta

Sondang P Siagian.,(2001) Manajemen Sumber Daya Manusia, Bumi Aksara, Jakarta

Sutrisno Edy, 2010. Manajemen Sumber Daya Manusia. Prenada Media Group. Jakarta. 